\title{
The moss flora of Gebel St. Katherine area (Sinai) with nine new records
}

\author{
Usama Y. Abou-Salama \\ Botany Department, Faculty of Science, \\ Ain Shams University, Cairo, Egypt. \\ E-mail: salama12000@Yahoo.com
} Abou-Salama U.Y. 2001. The moss flora of Gebel St. Katherine (Sinai) with nine new records. Taeckholmia
21(1):81-90.

Sixteen moss species representing eleven genera, six families and five orders are reported from Gebel St. Katherine area including nine new records. Mosses known from this area amount to 28 taxa. Diagnostic features, notes on morphology-habitat relations and moss abundance of the 16 taxa are provided and a key for the identification of the mosses known at present from the study area based on gametophytic characters is constructed.

Key Words: Egypt, Gebel St. Katherine mountain, Moss flora, Southern Sinai.

\section{Introduction}

Mountainous southern Sinai consists of a complex system of high and very rugged igneous and metamorphic mountains that are dissected by deep wadis (Said, 1990). It is delimited from the north by both Ugma plateau and El-Tih desert, from the southwest by El-Qaa plain and from the east by the shore of El-Aqaba Gulf (Fig. 1). Its central district is more elevated, has mean annual temperature of $9^{\circ}-15^{\circ} \mathrm{C}$, receives more precipitation than any other part of Sinai, but fog and dew are absent. Gebel St. Katherine is one of the prominent features which is located nearly in the center of this district (Fig. 1). This black mountain consists of old volcanic rocks and attains an altitude of $2642 \mathrm{~m}$ asl. being the highest in Egypt. It is the coldest area in Sinai; the mean monthly temperature ranges from $-1^{\circ} \mathrm{C}$ to $2^{\circ} \mathrm{C}$ in winter and $17^{\circ} \mathrm{C}$ to $19^{\circ} \mathrm{C}$ in summer. It receives about $65-100 \mathrm{~mm}$ of rainfall annually. Precipitation may also occur as snow and hail (Zahran \& Willis, 1992).

Lorentz (1867), reported from Gebel St. Katherine Eucladium verticillatum (Brid.) Bruch, Schimp. \& W. Gümbel, Rhynchostegium riparioides (Hedw.) Cardot (=Rhynchostegium rusciforme Bruch, Schimp. \& W. Gümbel) and Bryum syriacum Lorentz (=Webera sinaitica Lorentz). Out of the nine moss taxa recorded by Hart (1891) from Gebel St. Katherine, seven were new to its flora. These were; Encalypta vulgaris Hedw., Gymnostomum aeruginosum Sm. (=Hymenostylium rupestre Schwägr.), Grimmia laevigata (Brid.) Brid. (=Grimmia leucophaea Grev.), Schistidium apocarpum (Hedw.) Bruch \& Schimp. (=Grimmia apocarpa L.), Entosthodon attenuatus (Dicks.) Bryhn (=Entosthodon templetonii Schwägr.), Bryum turbinatum (Hedw.) Turner and Brachythecium velutinum (Hedw.) Bruch, Schimp. \& W. Gümbel (=Hypnum velutinum L.). To these, Geheeb (1903) added Didymodon tophaceus (Brid.) Lisa, Syntrichia inermis (Brid.) Bruch, Syntrichia rigescens (Broth. \& Geh.) Ochyra, Tortula kneuckeri Broth. \& Geh. and Grimmia anodon Bruch \& Schimp. Furthermore, Geheeb (1904) added Brachymenium exile (Dozy \& Molk.) Bosch \& Sande Lac. (incorrectly identified as 
Bryum caespiticium Hedw. cf. El-Saadawi, et al. 1999), Bryum gemmiparum De Not. and Pohlia atropurpurea (Wahlenb.) Lindb. (=Bryum atropurpureum Wahlenb.). Hymenostylium recurvirostrum (Hedw.) Dixon (=Hymenostylium recurvirostre Hedw.) was reported from Gebel St. Katherine by Bilewsky (1974) bringing the score up to 19 species from this mountain.

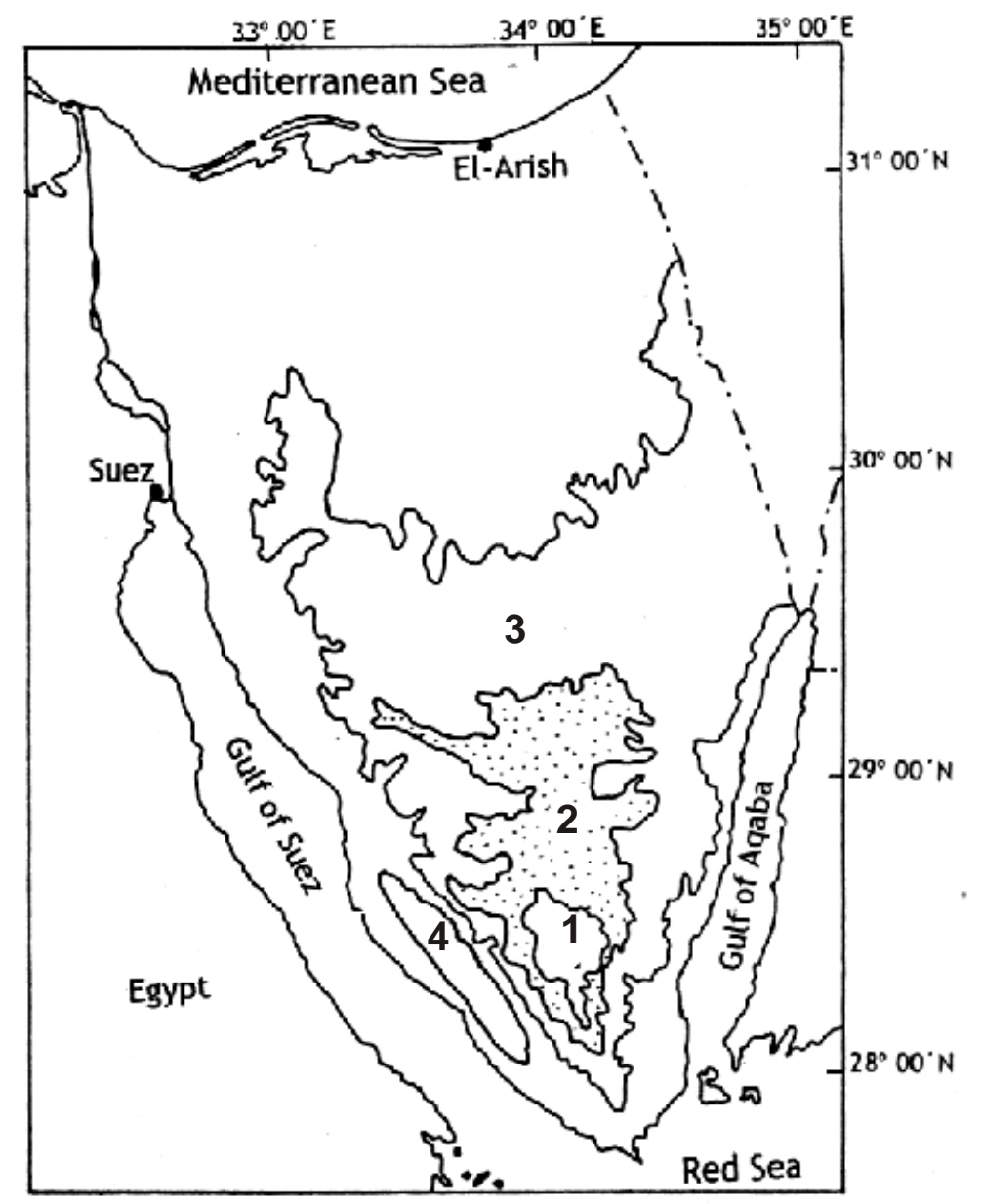

Fig. (1): Map showing the location of Gebel St. Katherine in Southern Sinai Massif. $1=$ Gebel St. Katherine (Igneous \& Metamorphic rocks; Basalt \& Granite). 2 = Ugma Plateau. 3 = El-Tih Desert. 4 = El-Qaa Plain.

\section{Materials and methods}

Twenty-nine moss samples were collected during May 1993 from wet to nearly dry rock crevices and from the edges and inside walls of a unique freshwater spring called Maayen (Bir) El-Shinnara (1900 m asl.) in Gebel St. Katherine area. This spring is located 
in a deep, windless, shaded, wet and very quiet place. Its waters come steadily from inside the rocks as well as percolating through rocks. Mesic and aquatic habitats favouring the luxurious growth of moss populations are widespread in this part of the Gebel.

Specimens were examined, sectioned according to Abou-Salama (1985) and Wilson (1990), and identified. Voucher specimens are kept in the Herbarium of the Botany Department, Faculty of Science, Ain Shams University (CAIA) and duplicates in the private collection of the author.

Identification was achieved by matching against authentic specimens kept in CAIA and by using keys, descriptions and illustrations in different moss floristic works (e.g. Flowers, 1973; Agnew and Vondracek, 1975; Nyholm, 1975; Smith, 1980 and Zander, 1993) as well as in some comprehensive treatments of specific taxa (e.g. Ochi, 1972). Classification, synonymy and epithets of authorities of plant names were followed as given in the recent updated list of Egyptian mosses (El-Saadawi, et al. 1999).

\section{Results}

The 29 collected samples yielded 18 entities, among which 16 entities were fully identified to the specific level. These species belong to eleven genera, six families and five orders, which are listed below $(*=$ new record to Gebel St. Katherine, $(* *=$ new record to Egypt):

Order: Pottiales

Family: Pottiaceae

Subfamily: Trichostomoideae

1. Eucladium verticillatum (Brid.) Bruch, Schimp. \& W. Gümbel

Subfamily: Merceyoideae

* 2. Didymodon luridus Hornsch.

3.D. tophaceus (Brid.) Lisa

* 4. Gymnostomun calcareum Nees \& Hornsch

* 5. Gyroweisia tenius (Hedw.) Schimp.

6. Hymenostylium recurvirostrum (Hedw.) Dixon

7. Tortula kneuckeri Broth. \& Geh.

Order: Grimmiales

Family: Grimmiaceae

8. Grimmia anodon Bruch \& Schimp.

Order: Bryales

Family: Bryaceae

* 9. Bryum caespiticium Hedw.

* 10. B. capillare Hedw.

* 11. B. funkii Schwägr.

* 12. B. pseudotriquetrium (Hedw.) P. Gaertn.

13. B. syriacum Lorentz

Order: Orthotrichales

Family: Orthotrichaceae

Order: Hypnales

** 14. Orthotrichum rupestre Schleich. Ex Schwägr.

Family 1: Amblystegiaceae

15. Amblystegium riparium (Hedw.) Bruch, Schimp. \& W. Gümbel 
Family 2: Brachytheciaceae

16. Rhynchostegium riparioides (Hedw.) Cardot

Number of pure gatherings, mixed gatherings, herbarium number together with diagnostic features of the identified species recorded from Maayen El-Shinnara are given below.

\section{1- Eucaldium verticillatum}

Leaves spreading to erecto-patent rarely patent, linear to linear-lanceolate, long and large towards tip; leaf margin plane, with serrulate cells just above base; leaf base pellucid with large wide rectangular and laxy cells; costa usually percurrent, stout, with 2 stereid bands and median guides. Stem without central strand.

Examined specimens: Pure gatherings: U.900, U.905, U.908, U.909, U.910, U.911 and U.913 (CAIA). Mixed gatherings: U.901b, U.902b and U.915b (CAIA).

\section{2- Didymodon luridus}

Leaves ovate, crowded at stem apex, widely keeled, quite fragile and with erect bases, papillose or papillose-crenulate recurved apical margins, percurrent or rarely ending below apex costa, leaf cells collenchymatous papillose especially abaxial surface.

Examined specimen: Mixed gathering: U.892b (CAIA).

\section{3- Didymodon tophaceus}

Plants olive-green; leaves \pm crowded above but equidistant below, mostly patent but sometimes erecto-patent to patent, upper leaves with erect base, usually ligulate; margin slightly recurved; apex obtuse to broadly acute; costa mostly ending below apex but occasionally percurrent; cells slightly papillose, clear, \pm uniform in size allover the leaf but wide rectangular at base near costa.

Examined specimens: Pure gathering: U.891 (CAIA). Mixed gatherings: U.901a and U.902a (CAIA).

\section{4- Gymnostomum calcareum}

Leaves erecto-patent to patent from usually erect base, not crowded, apex mostly broadly acute, rarely apiculate, margin plane, costa ending below apex, upper leaf cells usually opaque and densly papillose, basal leaf cells wide rectangular.

Examined specimens: Pure gatherings: U.907, U.917 (CAIA). Mixed gathering: U. 899a (CAIA).

\section{5- Gyroweissia tenuis}

Leaves erecrto-patent, ligulate, more crowded at apex, apex obtuse, margin plane and slightly papillose, costa ending just below apex, cells of leaf base wide and thin walled.

Examined specimens: Pure gathering: U.906 (CAIA). 


\section{6- Hymenostylium recurvirostrum}

Lingulate leaves, acute margin, stout costa, collenchymatous and papillose lamina cells, medium guides and the stem with very thick outer cortex and without central strand are the most important characters of this taxon.

Examined specimens: Mixed gathering: U.915c (CAIA).

\section{7- Tortula kneuckeri (endemic to Southern Sinai; Geheeb, 1903)}

Small delicate moss with short oblong soft leaves, slender hair point, delicate costa, smooth thin walled lamina cells, 1-3 rows of ventral guides and small stereid band, some leaves with asymmetrical blade, long perichaetial leaves, short cylindrical capsule and tesselate peristome with short membrane.

Examined specimens: Mixed gathering: U.898a (CAIA).

\section{8- Grimmia anodon}

Plants usually form hoary, dark green and usually pure cushions (or sometimes small mats), turn blackish when dry; Leaves crowded, erecto-patent, keeled, with long multiseriate decurrent down apecis and margins of lamina hyaline hair point (especially upper leaves), lamina cells bistratose especially towards leaf apex and obviously incrassate.

Examined specimens: Pure gatherings: U.894 and U.895 (CAIA).

\section{9- Bryum caespiticium}

Leaves small, up to $1.0 \mathrm{~mm}$ long, crowded especially at apex, imbricate, erect, strongly concave, ovate above but lanceolate below; costa excurrent to a long or short point; apex pointed outwards.

Examined specimens: Mixed gatherings: U.897b and U.899b (CAIA).

\section{0 - Bryum capillare}

Plants autoecious, with papillose rhizoids, rhizoidal gemmae \pm spheroidal, leaves more crowded at apices, broadest part of leaf above mid-leaf, margin usually serrulate at apex and bordered, costa excurrent to a long \pm stout point, base especially in old leaves usually with red colour.

Examined specimens: Mixed gatherings: U.893a, U.896a and U.898b (CAIA).

\section{1- Bryum funkii}

Leaves imbricate, strongly concave, short ovate or ovate-orbicular, equally spaced and crowded, stem jelaceous, costa excurrent to a short point in apical leaves but ending below apex in lower leaves.

Examined specimens: Pure gathering: U.914 (CAIA). Mixed gatherings: U.897a and U.916b (CAIA). 


\section{2- Bryum pseudotriquetrium}

Leaves crowded at stem apex, ovate to lanceolate, large, up to $3.0 \mathrm{~mm}$ long; with strongly bordered bistratose margin, apex acute; costa percurrent rarely very short excurrent especially in old leaves sometimes ending below apex in lower leaves, slightly pointed outwards.

Examined specimen: Pure gathering: U.918 (CAIA).

\section{3- Bryum syriacum}

Female plants were recorded, leaves bent to one direction, oblong ovate to long lanceolate, large, up to $3.0 \mathrm{~mm}$ long, apex acute, costa in upper leaves percurrent but in lower leaves ending below apex, lanceolate to ovate, margin bordered bi- and tri- stratose. Examined specimens: Pure gathering: U.890 (CAIA). Mixed gatherings: U.892a, U.896c, U.901c, U.903b and U.916a (CAIA).

\section{4- Orthotrichum rupestre}

Plant autoecious; leaves fragile, crowded, erecto-patent and patent, lanceolate-ligulate; apex obtuse-acute with soft apiculus; costa ending below apex; margin recurved; leaf cells collenchymatous, upper cells irregularly rounded and slightly papillose but rectangular and smooth below.

Examined specimen: Mixed gathering: U.901d (CAIA).

\section{5- Amblystegium riparium}

Stem with indistinct central strand; leaves crowded and \pm equidistant, vary in sizes forming alternate zones of small and large leaves, ovate, sometimes with asymmetrical blade, \pm slightly concave, mostly patent to spreading; apex acuminate to acute, mostly secund; margin serrulate especially towards leaf apex, plane, unbordered; costa usually percurrent, distinctly undulate at upper leaf part, slender, homogenous; cells obviously incrassate, rhomboidal rectangular pentagonal and hexagonal.

Examined specimens: Mixed gatherings: U.896b and U.903a (CAIA).

\section{6- Rhynchostegium riparioides}

Aquatic creeping robust moss with vigorously pinnately branched stem, leaves crowded and vary in sizes in alternate zones, serrulate apical leaf margin, costa so delicate and vanishing distinctly below apex, linear to vermicular lamina cells turning wide at base.

Examined specimen: Mixed gathering: U.915a (CAIA).

\section{Discussion}

From the results that have been presented, Eucladium verticillatum was found to be the most frequent taxon in the study area, being represented in ten samples. This is due to the fact that this moss exhibited a wide spectrum of morphological features that enables it to inhabit diverse habitats not only in Gebel St. Katherine but in the whole area of St. Katherine protectorate (Abou-Salama, 1991). The second most frequent taxon is Bryum syriacum being represented in six samples. On the other hand, seven taxa are represented 
in only one sample each, while seven others are represented in two or three samples each. Furthermore, three taxa occur in pure samples, eight in mixed samples while five in both pure and mixed ones.

Tortula knueckeri, Orthotrichum rupestre and Bryum capillare were recorded with both kinds of sex organs and the first was the only fruiting moss. It is worthy to mention that the present find of the endemic Tortula knueckeri is the second since the record of the type material by Geheeb (1903).

Orthotrichum rupestre is a new record to the bryoflora of Egypt. A single individual plant of this taxon was found in a mixed sample containing Eucladium verticillatum, Didymodon tophaceus and Bryum syriacum. More search in the area for niches accomodating populations of this newly recorded moss is recommended. It is a widespread taxon being reported from: Eur; Afr1, 2, 4; As2, 3, 5; Am1, 2, 6 and Aust1, 2. (Wijk, et al. 1964).

Didymodon luridus, Gymnostomum calcareum, Gyroweissia tenius, Bryum caespiticium, B. capillare, B. funkii, B. pseudotriquetrium, Orthotrichum rupestre and Amblystegium riparium are new records to the moss flora of Gebel St. Katherine. These bring the total number of mosses known from this area to 28 taxa.

These 28 taxa are included in 18 genera, eight families and seven orders, with Pottiaceae as the largest family. It is represented by ten taxa included in seven genera. Bryum is the most common as well as the largest genus being represented by seven taxa.

Due to rarity of fruiting, the following key is constructed based on the gametophytic characters of the 28 mosses. This would help for fast and easy identification for mosses known at present from this area.

1.a. Leaves with honeycomb areolation bryoid pattern with prosenchy-matous cells at apical and middle leaf parts, costa with ventral guides, leaf cells smooth, stem pentagonal in T. S.

b. No such combination of characters.................................................... 9

2.a. Leaf margin distinctly bordered, 2-3 raws ...................................... 3

b. Leaf margin unbordered.............................................................. 6

3.a. Marginal apical cells serrulate, costa excurrent to a long point, broadest leaf part above mid-leaf...................................... Bryum capillare

b. No such combination of characters .................................................... 4

4.a. Margin unistratose.................................................... B. turbinatum

b. Margin bi- or tristratose ............................................................. 5

5.a. Leaves crowded at stem apex, costa in old leaves short excurrent

B. pseudotriquetrum

b. Leaves equidistant, costa in old leves ending below apex ........... B. syriacum

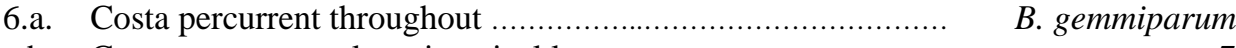

b. Costa excurrent at least in apical leaves.

7.a. Leaves short ovate or ovate-orbicular, strongly concave, costa excurrent in apical leaves but ending below apex in lower ones ...... B. funkii

b. Leaves ovate or lanceolate, costa excurrent throughout ............................ 8

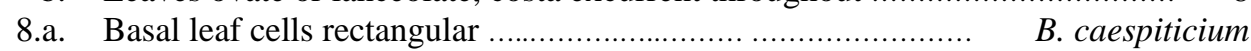

b. Basal leaf cells quadrangular ............................... Brachymenium exile

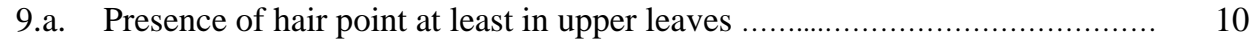

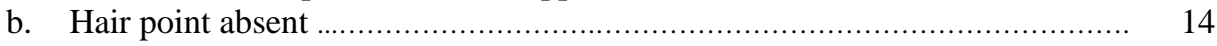


10.a. Hair point delicate, lamina cells unistratose

Tortula kneuckeri

b. Hair point long and hyaline or leaf tip hyaline, lamina cells partly or totally bistratose especially towards leaf apex

11.a. Leaf shape lingulate, not keeled

Syntrichia rigescens

b. Leaf shape long triangular to lanceolate, keeled

12.a. leaf apex with or without quite short hyaline smooth to spinulose hair point, margin recurved on at least one side

b. Leaf with long hyaline spinulose hair point, margin plane

13.a. Costa thickened towards apex

b. Costa widened towards base

G. laevigata

14.a. Leaves lanceolate to ovate or obovate, costa usually ending below apex, slender, leaf cells elongated hexagonal or rectangular, smooth, not chlorophyllose, central strand present at least above

b. No such combination of characters

15.a. Plants long ot median sized, leaves numerous, margin denticulate above, cells narrowly hexagonal not prosenchymatous, slightly incrassate

Pohlia atropurpurea

b. Plants small, leaves few, margin usually entire or with smoothly protruded cells, cells wide rectangular, thin walled and usually lax especially below

Entothodon attenuatus

16.a. Marginal leaf cells above base serrulate, basal leaf cells lax, central strand absent

b. No such combination of characters ................................................. 17.

17.a. Apical marginal cells serrulate, costa homogenous with a few stereids ........ 18

b. Apical marginal cells smooth or papillose, costa with ventral or median guides

18.a. Costa percurrent, leaf cells rhymboidal, rectangular or hexagonal

b. Costa vanishing far below apex, leaf cells vermicular or long rhomboidal ....

19.a.. Leaves lanceolate-triangular, apex with long acumen

Brachythecium velutinum

b. Leaves ovate or lanceolate, apex acute .............. Rhynchostegium riparioides

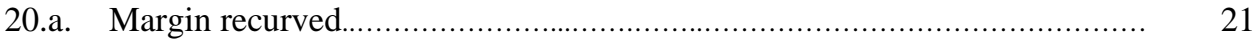

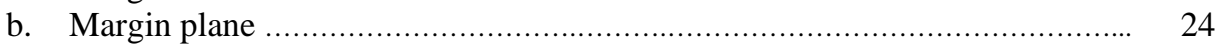

21.a. Leaf cells pluripapillate, leaves flaccid .......................... Syntrichia inermis

b. Leaf cells papillose or mamillose, leaves not flaccid or fragile .................. 22

22.a. Leaf apex apiculate .......................................... Orthotrichum rupestre

b. Leaf apex without apiculus .......................................................... 23

23.a. Leaves ligulate, apex mostly obtuse, leaf cells clear ..... Didymodon tophaceus

b. Leaves lanceolate or long ovate or long triangular, apex mainly acute, leaf cells opaque

D. luridus

24.a. Leaf apex acute, cells collenchymatous .............................................. 25

b. Leaf apex obtuse, cells not collenchymatous ........................................ 27

25.a. Costa percurrent, stout, with median guides, 
b. Costa ending below apex, usually homogenous, stem with central strand .....

26.a. Leaves linear, costa \pm uniform throughout, leaf cells collenchymatous

Gymnostomum aeruginosum

b. Leaves lanceolate or ovate, costa weakened below, cells not collencymatous

G. calcareum

27.a. Leaf cells pleuripapillate, costa percurrent or excurrent to a very short mucro, leaf base distinctly hyaline

Encalypta vulgaris

b. Leaf cells smooth, costa ending below apex, leaf base not hyaline

Gyrowesia tenius

\section{Concluding Remarks}

Bryolofloristical works on Egypt that began about two centuries ago were recently reviewed and updated by El-Saadawi, et al. (1999), revealing the presence of 168 moss taxa in the country. New records were added by Refai and El-Saadawi (2000), one taxon by Abou-Salama and El-Saadawi (2001a), another taxon by Abou-Salama and El-Saadawi (2001b) four taxa and the present work added one taxon; raising the number of mosses, hitherto, known from Egypt to 175 taxa. These were recorded in 12 (out of 15) phytogeographical territories (El-Hadidi \& Fayed, 1994/95) and the share of Sinai Massif territory was 85 taxa.

Although the site of Maayen El-Shinnara in Gebel St. Katherine is located at $1900 \mathrm{~m}$ a.s.l, yet its mosses share characters with those growing in deep Wadi beds. These characters include, the abundance of mixed samples, absence of or weakly formed central strand, rarity of fertility and fruit, abundance of mesic taxa (12 entities recorded), presence of aquatic mosses (Amblystegium riparium and Rhynchostegium riparioides) and rarity of xeric taxa (the ephemeral Tortula kneuckeri and the dark hoary Grimmia anodon).

\section{Acknowledgement}

Prof. Dr. W. El-Saadawi is greatly acknowledged for constructive criticism.

\section{References}

Abou-Salama U.Y. 1985. Morphological studies on some Egyptian bryophytes in Southern Sinai. M. Sc. Thesis, Bot. Dept. Fac. Sci., Ain Shams Univ. Cairo, Egypt. 1991. Studies on the Bryoflora of Egypt (Southern Sinai) with special reference to Genus Bryum. Ph. D. Thesis, Bot. Bot. Dept., Fac. Sci., Ain Shams Univ., Cairo, Egypt.

\& El-Saadawi W. E. 2001a. A contribution to the moss flora of Isthmic desert, Egypt. J. Bryol. 23(2):146-148.

2001b. Mosses of the Egyptian Oases Dakhla and Kharga. Lindbergia (submitted for publication).

Agnew S. \& Vondracek M. 1975. A moss flora of Iraq. Feddes Repertorium, Band 86, Heft 6-8: 341-489.

Bilewsky F. 1974. Some notes on the distribution of mosses in Israel and Palestine. Rev. Bryol. Lichenol. 40:245-261. 
El-Hadidi M. N. \& Fayed A. A. 1994/1995. Materials for Excursion Flora of Egypt (EFE). Taeckholmia, 15: 1-233.

El-Saadawi W.E., Badawi F., Shabbara H.M., Abou-Salama U.Y. and Refai M.S. 1999. An updated list of Egyptian mosses. Taeckholmia, 19(2):77-96.

Flowers S. 1973. Mosses of Utah and the West, Arther Holmgren (ed.). Brigham Young Univ. Press.

Geheeb A. 1903. Bryophyta.- In Kneucker A., Botanische Ausbeute einer Reise Durch die Sinaihalbinsel vom 27. März bis 13. April 1902.- Allg. Bot. Z. Syst.: 185-189, 203204

Geheeb A. 1904. Bryophyta.- In Kneucker A., Botanische Ausbeute einer Reise Durch die Sinaihalbinsel vom 27. März bis 13. April 1902.- Ibid.: 4-5.

Hart H.C. 1891. Some Account of The Founa and Flora of Sinai, Petra and Wady Arabah. London.

Lorentz P. G. 1867. Über die Moose, die Herr Ehrenberg in den Jahren 1820-1826 in Ägypten, der Sinai-halbinsel und Syrien gesammelt hat. Phys. Math. Abh. K. Akad. Wiss. Berlin, 1-57.

Nyholm E. 1975. Illustrated Moss Flora of Fennoscandia. Bot. Soc. Lund. II-Musci, Fasc 2,3. 2nd ed. Swedish Natural Science Research Council.

Ochi H. 1972. A Revision of African Bryoideae, Musci (First Part). The Journal of Faculty of Education, Tottori Univ. 24 (1), Koyama-Cho, Tottori, Japan.

Refai M. S. \& El-Saadawi, W. E. 2000. Contributions to the moss flora of the Isthmic desert, Sinai, Egypt. Taeckholmia, 20 (2): 139-146.

Said R. 1990. The Geology of Egypt. Balkema. Rotterdam, Brookfield.

Smith A.J.A. 1980. The Moss Flora of Britain and Ireland. Cambridge Univ. Press.

Wijk R., Margadant W. D. \& Florschutz P. A. 1964. Index Muscorum, 3, Regnum Vegetabile 33. Utrecht-Netherlands.

Wilson P. 1990. How to make thin free-hand sections. Evansia 7: 16.

Zahran M. A. \& Willis A. J. 1992. The vegetation of Egypt: 261-264.

Zander R.H. 1993. Genera of the Pottiaceae: Mosses of Harsh Environment. Bulletin of the Buffalo Society Natural Science. 32. Buffalo, N.Y. 